\title{
Kemampuan Pemecahan Masalah Matematis Pada Siswa SMK Ditinjau
} Dari Kecemasan Matematika

\author{
Fauziah Apriyani*, Adi Ihsan Imami \\ Pendidikan Matematika, Universitas Singaperbangsa Karawang, Karawang, Indonesia \\ *Coresponding Author: 1810631050096@student.unsika.ac.id
}

\begin{abstract}
The process of learning mathematics when face-to-face learning is limited for some students becomes stressful and can cause anxiety. The anxiety experienced by students can interfere with the learning process of mathematics, especially in students' ability to solve mathematical problems. The purpose of this study was to analyze how the mathematical problem solving ability of vocational students in terms of mathematics anxiety. The research method used is descriptive qualitative analysis with test and nontest data collection techniques. Non-test technique in the form of a questionnaire to assess the level of mathematics anxiety in students as well as a test technique in the form of description questions to see students' mathematical problem solving abilities. The sample in this study were students of class XI from one of the vocational schools in Jakarta as many as 27 students. This research was conducted in the odd semester of the 2021/2022 academic year. The results showed that students with low and very low math anxiety categories had very good mathematical problem solving abilities. Students with the category of moderate math anxiety have good mathematical problem solving skills. Students with high math anxiety category have sufficient problem solving abilities. Meanwhile, students with very bigh anxiety category have poor mathematical problem solving abilities.

Keywords: math anxiety; problem solving ability
\end{abstract}

Article History:

Received 2022-01-28

Revised 2022-02-16

Accepted 2022-03-01

DOI:

10.31949/educatio.v8i1.1973

\begin{abstract}
Abstrak
Proses pembelajaran matematika pada saat pembelajaran tatap muka terbatas untuk sebagian siswa menjadi hal yang menegangkan dan dapat menimbulkan rasa cemas. Rasa cemas yang di alami siswa dapat mengganggu proses pembelajaran matematika terutama pada kemampuan siswa dalam pemecahan masalah matematis. Tujuan dari penelitian ini adalah untuk menganalisis bagaimana kemampuan pemecahan masalah matematis pada siswa SMK ditinjau dari kecemasan matematika. Metode penelitian yang digunakan adalah analisis deskriptif kualitatif dengan teknik pengumpulan data tes dan non tes. Teknik non tes berupa angket untuk menilai tingkat kecemasan matematika pada siswa serta teknik tes berupa soal uraian untuk melihat kemampuan pemecahan masalah matematis siswa. Sampel dalam penelitian ini adalah siswa kelas XI dari salah satu SMK di Jakarta sebanyak 27 siswa. Penelitian ini dilaksanakan pada semester ganjil tahun ajaran 2021/2022. Hasil penelitian menunjukkan bahwa siswa dengan kategori kecemasan matematika rendah dan sangat rendah memiliki kemampuan pemecahan masalah matematis yang sangat baik. Siswa dengan kategori kecemasan matematika sedang memiliki kemampuan pemecahan masalah matematis yang baik. Siswa dengan kategori kecemasan matematika tinggi memiliki kemampuan pemecahan masalah yang cukup. Sedangkan siswa dengan kategori kecemasan sangat tinggi memiliki kemampuan pemecahan masalah matematis yang kurang.
\end{abstract}

Kata Kunci: kecemasan matematika; kemampuan pemecahan masalah

\section{PENDAHULUAN}

Kegiatan belajar mengajar di Indonesia saat ini menggunakan sistem pembelajaran yang terus berganti mengikuti situasi pandemic covid-19. Berdasarkan SKB Empat Menteri Tentang Panduan Penyelenggaraan Pembelajaran Di Masa Pandemic Coronavirus Disease 2019 (Covid-19) bahwa kegiatan belajar mengajar saat ini menggunakan sistem Pembelajaran Tatap Muka Terbatas (PTMT) dengan peraturan-peraturan yang telah ditetapkan oleh pemerintah. Hal ini membuat siswa yang sudah terbiasa dengan Pembelajaran Jarak Jauh (PJJ) harus beradaptasi kembali dengan sistem pembelajaran yang baru. Interaksi yang biasanya dilakukan secara 
daring kini kembali dilaksanakan di dalam kelas dengan jumlah siswa yang terbatas dan waktu pembelajaran yang lebih singkat. Dari hasil wawancara dengan siswa mengenai pembelajaran matematika saat PTMT didapatkan hasil bahwa siswa merasa takut, cemas, dan kebingungan saat diskusi soal-soal matematika atau pun merasa tegang saat diminta untuk menyelesaikan soal di papan tulis. Siswa juga merasa tidak bisa fokus saat pembelajaran matematika. Rasa cemas dapat dialami oleh siapa saja dan dimana saja. Menurut Anita (2014) rasa cemas yang dirasakan siswa saat belajar matematika disebut dengan kecemasan matematika (Mathematics Anxiety).

Richardson dan Suinn (I. W. Anita, 2014) menyatakan bahwa kecemasan matematika melibatkan perasaan tegang dan cemas yang mempengaruhi pada kehidupan nyata maupun akademik saat menyelesaikan soal matematika. Menurut Ashcraft (Setyawati \& Ratu, 2021) kecemasan matematika adalah sebuah perasaan tegang, cemas bahkan ketakutan yang dapat mengganggu dalam kinerja matematika. Menurut Mulyana et al. (2021) indikator kecemasan matematika terdiri dari tiga aspek yaitu 1) aspek kognitif (konsentrasi rendah, kebingungan, sulit memahami materi, tidak mampu mengerjakan soal sendiri, kepercayaan diri rendah, dan khawatir); 2) aspek afektif (kesal, cemas, gelisah, gugup, dan takut); 3) aspek psikomotorik (tidak mau mengikuti pembelajaran matematika dan menghindari segala sesuatu yang berhubungan dengan matematika). Kecemasan yang di alami siswa saat pembelajaran matematika dapat mempengaruhi kemampuan pemecahan masalah matematisnya. Pernyataan ini sejalan dengan pendapat Sieber (Ikhsan, 2019) bahwa kecemasan merupakan salah satu faktor penghambat dalam belajar sehingga dapat mengganggu kemampuan kognitif seseorang, seperti sulit berkonsentrasi, mengingat, membentuk suatu konsep, dan untuk pemecahan masalah.

Kemampuan pemecahan masalah matematis merupakan kemampuan kognitif yang sangat penting dan wajib dimiliki oleh setiap siswa. Kemampuan pemecahan masalah dapat membantu siswa dalam menyelesaikan permasalahan dalam bidang pendidikan atau pun digunakan dalam kehidupan sehari-hari. Kemampuan pemecahan masalah menurut Agsya et al. (2019) adalah suatu kemampuan berfikir tingkat tinggi dimana siswanya dapat menggabungkan seluruh pengetahuan yang sudah ia miliki menjadi suatu pengetahuan baru sehingga dapat digunakan untuk menyelesaikan permasalahan yang berbeda. Menurut Rahmmatiya \& Miatun (2020) penggunaan metode, prosedur, dan strategi yang kebenarannya dapat dibuktikan secara sistematis merupakan fokus pemecahan masalah dalam pembelajaran matematika. Langkah-langkah pemecahan masalah yang dikemukakan Polya (Vendiagrys et al., 2015) meliputi: 1) memahami masalah; 2) membuat rencana; 3) melaksanakan rencana; 4) memeriksa kembali.

Berdasarkan beberapa penelitian terdahulu, antara lain penelitian Setyawati \& Ratu (2021) dengan sampel penenlitian siswa SMP menyatakan bahwa tingkat kecemasan matematika yang berbeda memberikan pengaruh terhadap kesulitan belajar siswa yang berbeda pula; Aunurrofiq \& Junaedi (2017); Hidayat \& Ayudia (2019); Rizki et al. (2019) dengan sampel penelitian siswa SMA; dan Lestari et al. (2020) dengan sampel penelitian siswa MTs menyatakan tingkat kecemasan matematika memberikan dampak negatif terhadap kemampuan pemecahan masalah matematis siswa, artinya semakin tinggi tingkat kecemasan matematikanya maka semakin rendah kemampuan pemecahan masalah yang dimiliki siswa dan berlaku untuk sebaliknya. Sedangkan dalam penelitian Ikhsan (2019) kecemasan dengan intensitas wajar atau rendah dapat memberikan nilai positif berupa semangat atau dorongan untuk memperbaiki kekurangan pada dirinya, tetapi apabila intensitasnya tinggi dan bersifat negatif maka kecemasan dapat menimbulkan kerugian serta dapat mengganggu keadaan fisik dan psikis seseorang.

Sudah banyak penelitian yang mengangkat topik tentang pengaruh kecemasan matematika dan kemampuan pemecahan masalah, tetapi peneliti belum menemukan penelitian dengan metode analisis deskriptif mengenai topik kemampuan pemecahan masalah matematis ditinjau dari kecemasan matematika. Peneliti juga menemukan bahwa dalam penelitian matematika masih jarang peneliti yang menggunakan sampel siswa SMK pada penelitiannya. Sehingga pada penelitian ini, peneliti ingin menganalisis lebih jauh mengenai kemampuan pemecahan masalah pada siswa SMK jika ditinjau dari kecemasan matematikanya. Penelitian ini diharapkan dapat memberikan informasi baru tentang kemampuan pemecahan masalah pada siswa SMK jika ditinjau dari kecemasan matematikanya, sehingga guru atau tenaga pendidik dapat mencari 
solusi untuk meminimalkan dampak negatif kecemasan matematika dan menurunkan tingkat kecemasan matematika siswa.

\section{METODE PENELITIAN}

Penelitian ini bertujuan untuk menganalisis bagaimana kemampuan pemecahan masalah pada siswa SMK jika ditinjau dari kecemasan matematikanya. Metode penelitian yang digunakan adalah analisis deskriptif kualitatif dengan teknik pengumpulan data berupa tes dan non tes yaitu menggunakan angket dan tes yang berupa soal uraian. Sampel yang digunakan pada penelitian ini adalah siswa kelas XI jurusan Rekayasa Perangkat Lunak (RPL) dari salah satu SMK di Jakarta sebanyak 27 siswa yang dilaksanakan pada semester ganjil tahun ajaran 2021/2022, tepatnya pada bulan November tahun 2021. Tahapan penelitian yang dilakukan sebagai berikut:

Tahap pertama yaitu mempersiapan instrument penelitian berupa instrument tes dan non tes. Instrument tes berbentuk soal uraian materi nilai mutlak dengan kemampuan pemecahan masalah matematis yang diadaptasi dari Wati (2021) dan instrument non tes berbentuk angket kecemasan matematika yang terdiri dari 29 pernyataan. Instrument non tes yang digunakan pada penelitian ini di adaptasi dari Rangkuti (2017) yang terbagi dalam 4 tingkat yaitu Sangat Tidak Setuju (STS), Tidak Setuju (TS), Setuju (S), dan Sangat Setuju (SS). Tahap kedua yaitu pelaksanaan penelitian. Sampel yang digunakan pada penelitian ini dipilih berdasarkan saran guru mata pelajaran matematika di sekolah tersebut. Penelitian dilakukan dengan memberikan link google form kepada siswa yang berisi angket dan soal pemecahan masalah. Tahap ketiga adalah melakukan analisis hasil data angket yang diolah dengan teknik pengolahan data menurut Sudijono (Hakim \& Adirakasiwi, 2021). Selanjutnya siswa di kelompokkan berdasarkan tingkat kecemasan matematika serta memeriksa jawaban soal pemecahan masalah. Adapun cara perhitungan nilai akhir untuk kemampuan pemecahan masalah adalah sebagai berikut:

$$
N=\frac{\text { skor perolehan }}{\text { skor maksimal }} \times 100
$$

dengan $N$ sebagai nilai akhir siswa. Nilai akhir siswa yang diperoleh kemudian dikategorikan sesuai dengan tabel 1.

Tabel 1 Kategori Kemampuan Pemecahan Masalah

\begin{tabular}{ll}
\hline \multicolumn{1}{c}{ Nilai } & \multicolumn{1}{c}{ Kategori } \\
\hline $85,00-100$ & Sangat baik \\
$70,00-84,99$ & Baik \\
$55,00-69,99$ & Cukup \\
$40,00-54,99$ & Kurang \\
$0-39,99$ & Sangat Kurang \\
\hline \multicolumn{2}{c}{ Sumber Japa (Mawaddah \& Anisah, 2015) }
\end{tabular}

Tahap terakhir yaitu mendeskripsikan hasil kemampuan pemecahan masalah matematis siswa ditinjau dari kecemasan matematika

\section{HASIL DAN PEMBAHASAN}

Berdasarkan data yang diperoleh dari angket kecemasan matematika, kategori kecemasan matematika siswa terbagi menjadi sangat tinggi, tinggi, sedang, rendah, dan sangat rendah.

Tabel 2. Hasil Angket Kecemasan Matematika Siswa

\begin{tabular}{lcc}
\hline \multicolumn{1}{c}{ Kategori Tingkat } & Kriteria Skor & Jumlah siswa \\
\hline Kangat Tinggi & Skor $>84$ & 1 \\
Tinggi & $74<$ Skor $\leq 84$ & 10 \\
Sedang & $64<$ Skor $\leq 74$ & 8 \\
Rendah & $55<$ Skor $\leq 64$ & 6 \\
Sangat Rendah & Skor $\leq 55$ & 2 \\
\hline
\end{tabular}

Open Access: https://ejournal.unma.ac.id/index.php/educatio 
Dari tabel 2 dapat kita ketahui bahwa dari 27 siswa kelas XI yang menjadi sampel pada penelitian ini, siswa dengan kategori kecemasan tinggi menjadi kelompok yang memiliki siswa terbanyak yaitu 10 siswa. Siswa dengan kategori kecemasan sedang sebanyak 8 siswa. Siswa dengan kategori kecemasan rendah sebanyak 6 siswa. Siswa dengan kategori sangat rendah sebanyak 2 siswa dan 1 siswa dengan kategori kecemasan sangat tinggi.

Tabel 3. Hasil Tes Kemampuan Pemecahan Masalah Siswa

\begin{tabular}{clc}
\hline Nilai & \multicolumn{1}{c}{ Kualifikasi } & Jumlah Siswa \\
\hline $85,00-100$ & Sangat baik & 5 \\
$70,00-84,99$ & Baik & 11 \\
$55,00-69,99$ & Cukup & 7 \\
$40,00-54,99$ & Kurang & 4 \\
$0-39,99$ & Sangat Kurang & - \\
\hline
\end{tabular}

Dari tabel 3 dapat kita ketahui bahwa kualifikasi pemecahan masalah baik menjadi kelompok dengan jumlah siswa terbanyak yaitu 11 siswa. Siswa dengan kualifikasi pemecahan masalah sangat baik sebanyak 5 siswa. Siswa dengan kualifikasi pemecahan masalah cukup sebanyak 7 siswa dan 4 siswa dengan kualifikasi pemecahan masalah kurang, sedangkan untuk kualifikasi sangat kurang tidak ada. Berikut ini adalah analisis kemampuan pemecahan masalah matematis siswa ditinjau dari kecemasan matematikanya.

\section{Kemampuan Pemecahan Masalah Siswa Dengan Kategori Kecemasan Matematika Sangat \\ Rendah}

Berdasarkan hasil tes yang telah dilakukan peneliti dengan S-6 diketahui S-6 dengan kategori kecemasan matematika sangat rendah memiliki kemampuan pemecahan masalah yang sangat baik. Hasil ini sejalan dengan penelitian Hakim \& Adirakasiwi (2021) yang menyatakan bahwa siswa dengan kategori kecemasan matematika sangat rendah mampu menyelesaikan permasalahan matematika dengan baik.

Soal nomor 1

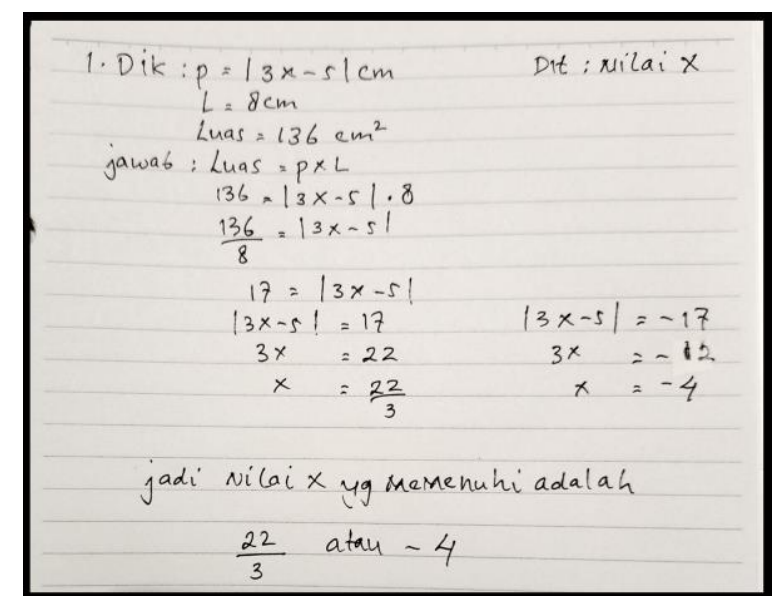

Gambar 1. Jawaban soal nomor 1 S-6

Langkah pertama dari kemampuan pemecahan masalah menurut polya yaitu memahami masalah yang terdapat pada soal. S-6 dapat menuliskan serta menjelaskan apa yang diketahui dan ditanyakan dari soal nomor 1 yaitu ukuran panjang persegi panjang $|3 x-5| \mathrm{cm}$, luas persegi panjang $136 \mathrm{~cm}^{2}$ dan lebar persegi panjang $8 \mathrm{~cm}$, serta yang ditanyakan yaitu menentukan nilai $x$ yang memenuhi. Langkah kedua dari kemampuan pemecahan masalah yaitu membuat rencana penyelesaian. S-6 mampu membuat serta menjelaskam rencana untuk menyelesaikan soal. Dengan menggunakan informasi yang sudah ada, S-6 dapat memperoleh informasi yang belum diketahui pada soal. S-6 menggunakan rumus luas persegi panjang $L=p x$ $l$ untuk menentukan persamaan nilai mutlak linear satu variabel yaitu $|3 x-5|=17$. Dilanjutkan dengan langkah ketiga dari kemampuan pemecahan masalah yaitu melaksanakan rencana penyelesaian. S-6 mampu menggunakan dan menjelaskan definisi nilai mutlak linear satu variabel untuk $|x|=x$, jika $x \geq 0$ dan $|x|=-x$, jika $x<0$ untuk mendapatkan nilai $x$. Langkah terakhir dari kemampuan pemecahan masalah 
yaitu memeriksa kembali. S-6 mampu memeriksa kembali setiap tahapan atau proses penyelesaian serta jawaban dari soal yang diselesaikan, dan S-6 mampu menuliskan kesimpulan dengan tepat.

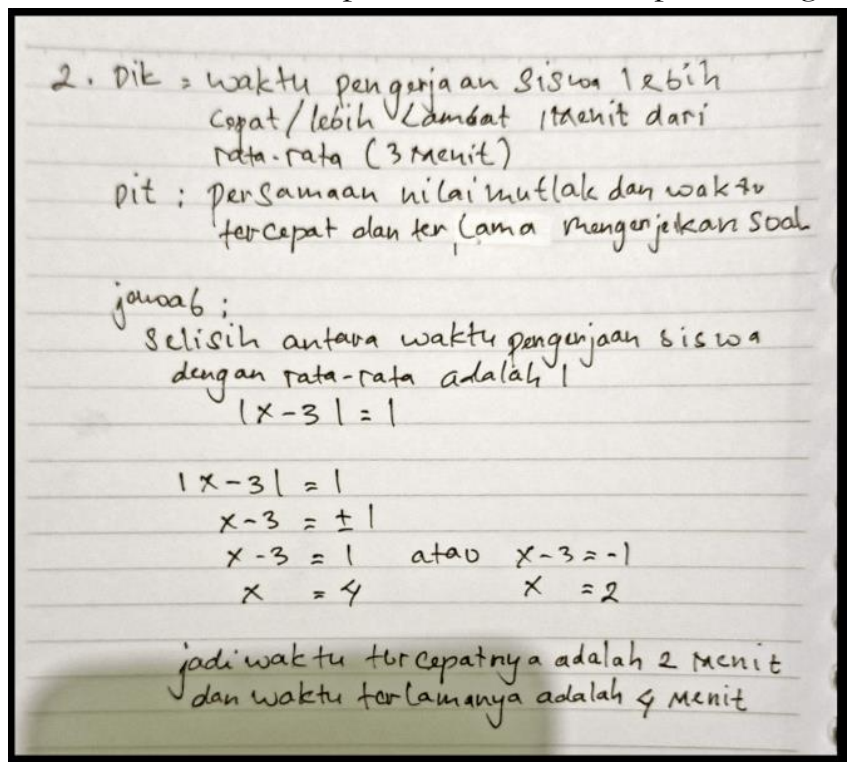

Gambar 2. Jawaban soal nomor 2 S-6

Pada soal nomor 2, S-6 juga mampu menyelesaikan langkah pertama pemecahan masalah yaitu memahami masalah yang terdapat pada soal dengan menuliskan serta menjelaskan apa yang diketahui dan ditanyakan dari soal nomor 2 yaitu waktu rata-rata siswa mengerjakan soal adalah 3 menit, serta yang ditanyakan yaitu persamaan nilai mutlak serta menentukan waktu tercepat dan terlama seorang siswa mengerjakan soal. Langkah kedua yaitu membuat rencana penyelesaian. S-6 mampu membuat dan menjelaskan rencana untuk menyelesaikan soal yaitu dengan menggunakan definisi nilai mutlak linear satu variabel. S-6 menuliskan persamaan $|x-3|=1$ pada lembar jawaban. Dilanjutkan dengan melaksanakan rencana penyelesaian. S-6 mampu menggunakan dan menjelaskan definisi nilai mutlak linear satu variabel untuk $|x|=x$, jika $x \geq 0$ dan $|x|=-x$, jika $x<0$ untuk mendapatkan waktu tercepat dan terlama siswa mengerjakan suatu soal. Langkah terakhir yaitu memeriksa kembali. Langkah ini dilakukan S-6 dan S-6 mampu menuliskan kesimpulan.

\section{Kemampuan Pemecahan Masalah Siswa Dengan Kategori Kecemasan Matematika Rendah}

Berdasarkan hasil tes yang telah dilakukan peneliti dengan S-21 diketahui S-21 dengan kategori kecemasan matematika rendah memiliki kemampuan pemecahan masalah yang sangat baik. Hasil ini sejalan dengan penelitian Ningsih (2016) yang menyatakan bahwa siswa dengan kategori kecemasan matematika rendah mampu memahami masalah, membuat rencana penyelesaian, melaksanakan rencana penyelesaian, kecuali pada tahap memeriksa kembali.

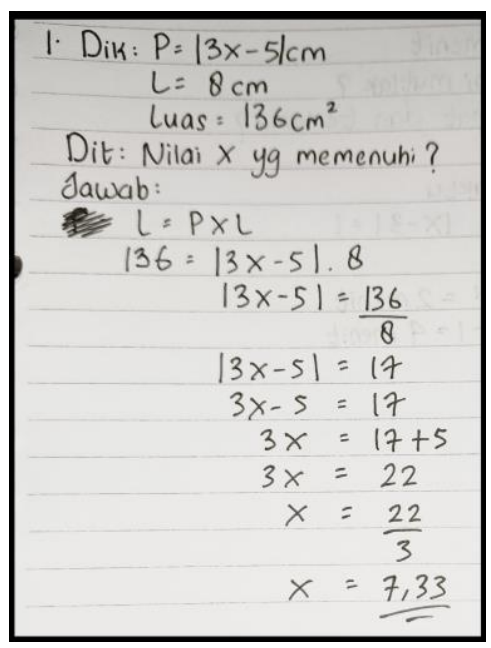


Gambar 3. Jawaban soal nomor 1 S-21

Pada soal nomor 1, S-21 mampu memahami masalah yang terdapat pada soal. S-21 dapat menuliskan serta menjelaskan apa yang diketahui dan apa yang ditanyakan dari soal nomor 1. Dilanjutkan dengan membuat rencana penyelesaian. S-21 mampu membuat dan menjelaskan rencana untuk menyelesaikan soal yaitu dengan menggunakan rumus luas persegi panjang $L=p \times l$ untuk menentukan persamaan nilai mutlak linear satu variabel. Setelah membuat rencana, langkah selanjutnya yaitu melaksanakan rencana penyelesaian. S-21 mampu menggunakan dan menjelaskan definisi nilai mutlak linear satu variabel untuk $|x|=x$, jika $x \geq 0$ tetapi S-21 tidak mampu untuk menyelesaikan $|x|=-x$, jika $x<0$. Langkah terakhir yaitu memeriksa kembali. Langkah ini dilakukan S-21 untuk memeriksa setiap tahapan atau proses penyelesaian dan jawaban dari soal yang diselesaikan tetapi S-21 tidak menuliskan kesimpulan.

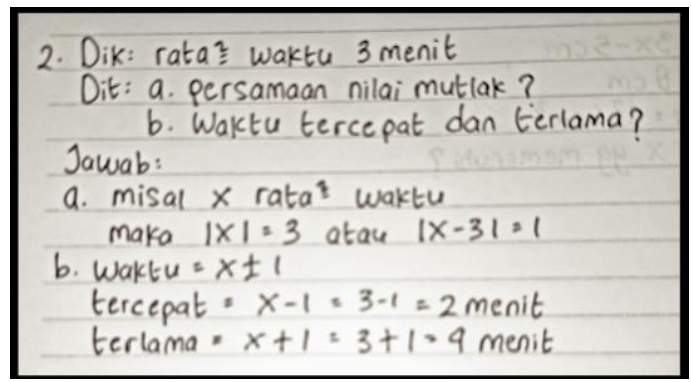

Gambar 4. Jawaban soal nomor 2 S-21

S-21 mampu memahami masalah yang terdapat pada soal. S-21 dapat menuliskan serta menjelaskan apa yang diketahui dan apa yang ditanyakan dari soal nomor 2. Dilanjutkan dengan membuat rencana penyelesaian. S-21 mampu membuat dan menjelaskan rencana untuk menyelesaikan soal yaitu dengan menggunakan definisi nilai mutlak linear satu variabel. S-21 menuliskan persamaan $|x-3|=1$ pada lembar jawaban. Setelah membuat rencana penyelesaian dilanjutkan dengan melaksanakan rencana penyelesaian. S-21 mampu menggunakan dan menjelaskan definisi nilai mutlak linear satu variabel untuk mendapatkan waktu tercepat dan terlama siswa mengerjakan suatu soal. Langkah terakhir yaitu memeriksa kembali. Langkah ini dilakukan S-21 untuk memeriksa setiap tahapan atau proses penyelesaian dan jawaban dari soal yang diselesaikan, serta S-21 mampu menuliskan kesimpulan dengan tepat.

\section{Kemampuan Pemecahan Masalah Siswa Dengan Kategori Kecemasan Matematika Sedang}

Berdasarkan hasil tes yang telah dilakukan peneliti dengan S-4 diketahui siswa S-4 dengan kategori kecemasan matematika sedang memiliki kemampuan pemecahan masalah yang baik. Hasil ini sejalan dengan penelitian Hakim \& Adirakasiwi (2021) yang menyatakan bahwa siswa dengan kategori kecemasan matematika sedang mengalami perasaan gelisah sehingga hasil tes kurang memuaskan.

\begin{tabular}{|c|c|}
\hline 1. & OK = Panjang Perseai Panfaing $13 x-51 \mathrm{~cm}$ dan \\
\hline$\square$ & lebar $8 \mathrm{~cm}$. Luas porseal pantang a dabah $136 \mathrm{~cm}^{2}$ \\
\hline$\square$ & ale = Tenwkan nilai $x$ ya memenuhi? \\
\hline$\square$ & Dis $=13-5 \times 1 \cdot 8^{\prime}=136^{17}$ \\
\hline$\square$ & $13-5 \times 1=17$ \\
\hline$\square$ & \\
\hline$\square$ & $b$ \\
\hline$\square$ & $-(3.5 \times)=17$ \\
\hline$\square$ & $-3+5 x=17$ \\
\hline$\square$ & $5 x=20$ \\
\hline$\square$ & $x=4$ \\
\hline$\square$ & $=$ Sadi, nivai $\times$ ra memenuni \\
\hline$\square$ & $14 \quad a+a 44$ \\
\hline$\square$ & 5 \\
\hline
\end{tabular}

Gambar 5. Jawaban soal nomor 1 S-4

S-4 mampu memahami masalah yang terdapat pada soal. S-4 dapat menuliskan dan menjelaskan apa yang diketahui dan apa yang ditanyakan dari soal nomor 1. Dilanjutkan dengan membuat rencana penyelesaian. S-4 
mampu membuat rencana penyelesaian tetapi tidak tepat. Hal ini terjadi akibat S-4 salah menuliskan persamaan nilai mutlak linear satu variabel. Sehingga S-4 tidak mampu melaksanakan rencana penyelesaian dengan baik walaupun sebenarnya S-4 mampu menerapkan definisi nilai mutlak linear satu variabel serta kesimpulan yang dibuat S-4 pun menjadi salah.

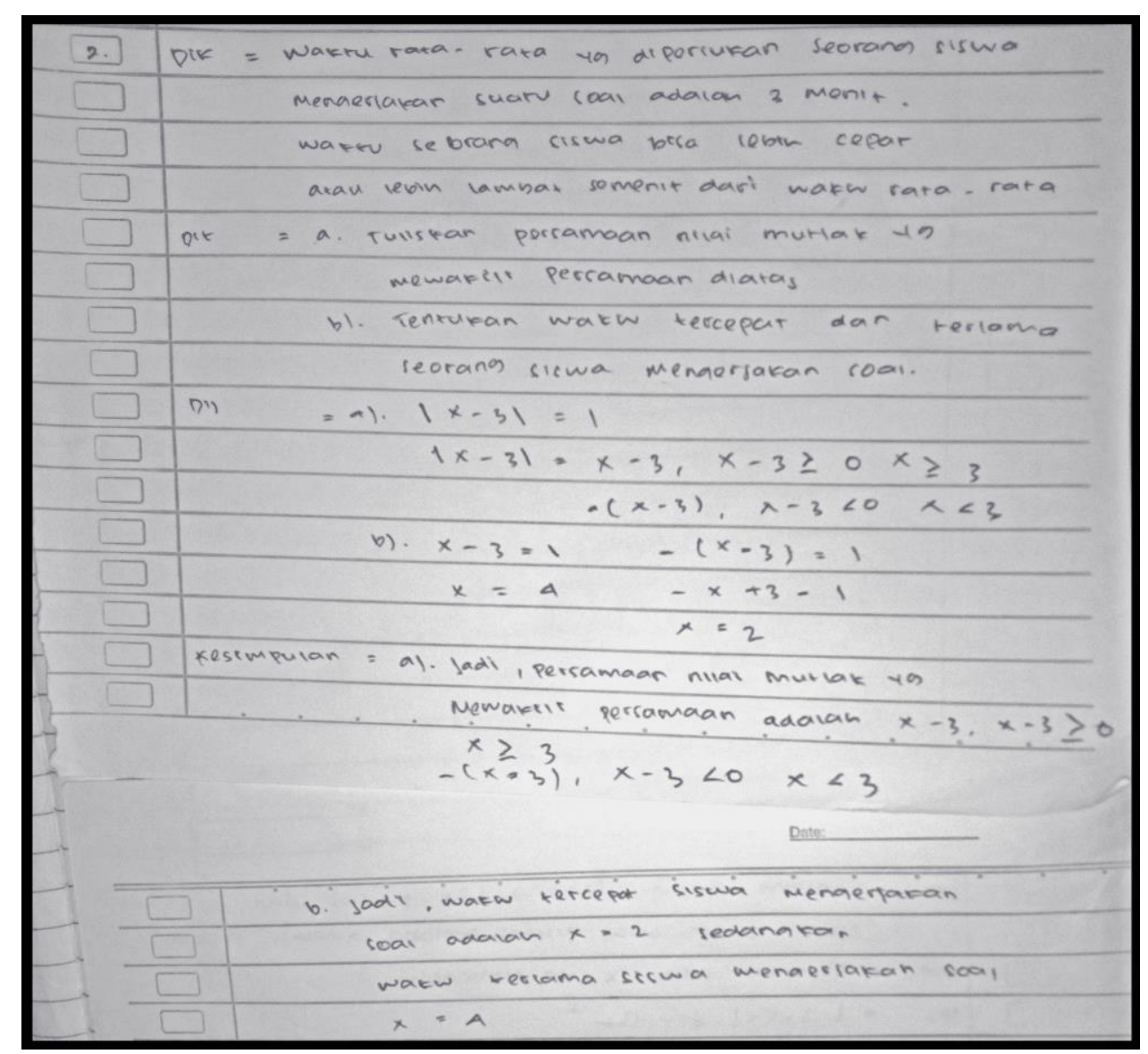

Gambar 6. Jawaban soal nomor 2 S-4

S-4 mampu memahami masalah yang terdapat pada soal. S-4 dapat menuliskan dan menjelaskan apa yang diketahui dan apa yang ditanyakan dari soal nomor 2. Langkah kedua membuat rencana penyelesaian. S4 mampu membuat dan menjelaskan rencana untuk menyelesaikan soal yaitu dengan menggunakan definisi nilai mutlak. S-4 menuliskan persamaan nilai mutlak $|x-3|=1$ pada lembar jawaban. Dilanjutkan dengan melaksanakan rencana penyelesaian. Siswa S-11 mampu menggunakan dan menjelaskan definisi nilai mutlak linear satu variabel. Langkah terakhir yaitu memeriksa kembali, langkah ini dilakukan S-4 serta S-4 mampu membuat kesimpulan dengan tepat.

\section{Kemampuan Pemecahan Masalah Siswa Dengan Kategori Kecemasan Matematika Tinggi}

Berdasarkan hasil tes yang telah dilakukan peneliti dengan S-18 diketahui S-18 dengan kategori kecemasan matematika tinggi memiliki kemampuan pemecahan masalah yang cukup. Hasil penelitian ini sejalan dengan penelitian Satriyani (2016) yang menyatakan bahwa siswa dengan kategori kecemasan matematika tinggi mengalami kesalahan dalam memahami masalah, sehingga jawaban pada tahapan berikutnya tidak sesuai dengan pertanyaan yang diajukan.

S-18 tidak mampu menyelesaikan langkah pemecahan masalah yang pertama yaitu memahami masalah yang terdapat pada soal. S-18 menuliskan apa yang diketahui dan apa yang ditanyakan dari soal nomor 1 tetapi salah. S-18 menuliskan yang diketahui untuk ukuran panjang persegi panjang $|3-5 x| \mathrm{cm}$. Seharusnya siswa menuliskan $|3 x-5| \mathrm{cm}$. Langkah kedua membuat rencana penyelesaian. S-18 mampu membuat rencana untuk menyelesaikan soal dengan menggunakan rumus luas persegi panjang $L=p \times l$ untuk menentukan 
persamaan nilai mutlak linear satu variabel namun S-18 tidak tepat dalam mensubstitusi ukuran panjang persegi panjang sehingga rencana penyelesaian salah.

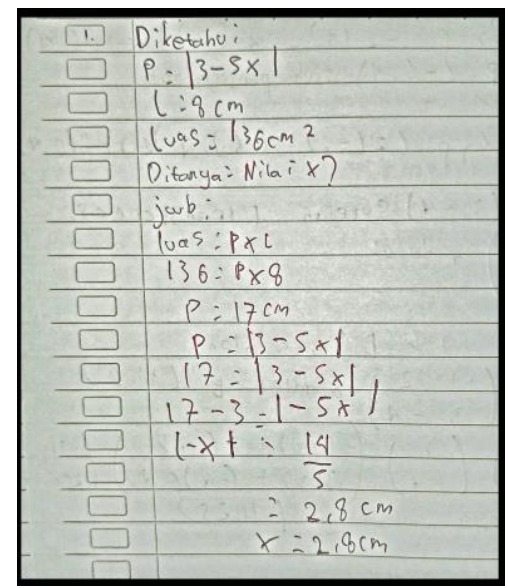

Gambar 7. Jawaban soal nomor 1 S-18

Langkah selanjutnya yaitu melaksanakan rencana penyelesaian. S-18 tidak mampu melaksanakan rencana penyelesaian dengan tepat. Langkah terakhir yaitu memeriksa kembali. Langkah ini tidak dilakukan oleh S-18 dan S-18 tidak menuliskan kesimpulan.

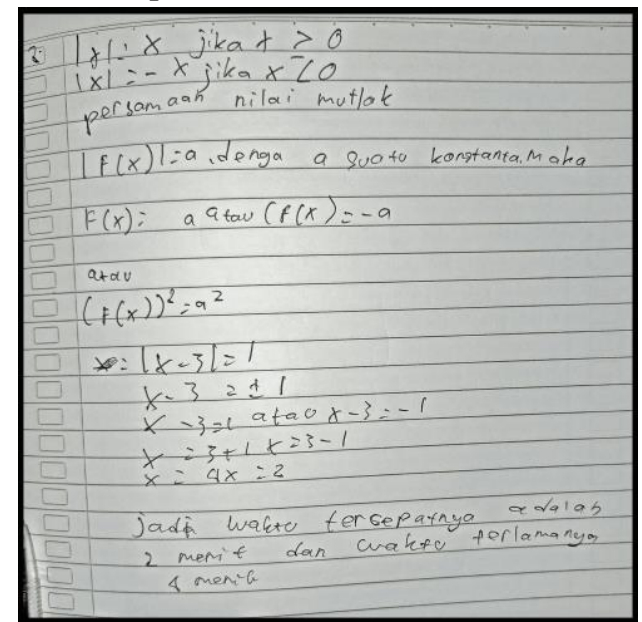

Gambar 8. Jawaban soal nomor 2 S-18

S-18 mampu memahami masalah yang terdapat pada soal. S-18 dapat menjelaskan apa yang diketahui dan apa yang ditanyakan dari soal nomor 2. Namun S-18 tidak menuliskannya pada lembar jawaban. Langkah kedua yaitu membuat rencana penyelesaian. S-18 mampu membuat dan menjelaskan rencana untuk menyelesaikan soal yaitu dengan menggunakan definisi nilai mutlak linear satu variabel. S-18 menuliskan persamaan $|x-3|=1$ pada lembar jawaban. Dilanjutkan dengan melaksanakan rencana penyelesaian yaitu dengan menggunakan definisi nilai mutlak linear satu variabel untuk mendapatkan waktu tercepat dan terlama siswa mengerjakan suatu soal. Langkah terakhir yaitu memeriksa kembali. Langkah ini tidak dilakukan oleh S18 dan menuliskan kesimpulan dengan tepat.

\section{Kemampuan Pemecahan Masalah Siswa Dengan Kategori Kecemasan Matematika Sangat Tinggi}

Berdasarkan hasil tes yang telah dilakukan peneliti dengan siswa S-1 diketahui siswa S-1 dengan kategori kecemasan matematika sangat tinggi memiliki kemampuan pemecahan masalah yang kurang. Hasil penelitian ini sejalan dengan penelitian N. Anita et al. (2019) yang menyatakan bahwa siswa dengan kategori kecemasan matematika sangat tinggi tidak mampu memahami masalah dengan baik, ketika membuat rencana penyelesaian siswa mengalami hambatan sehingga tidak mampu menyelesaikan rencana yang telah dibuat. 


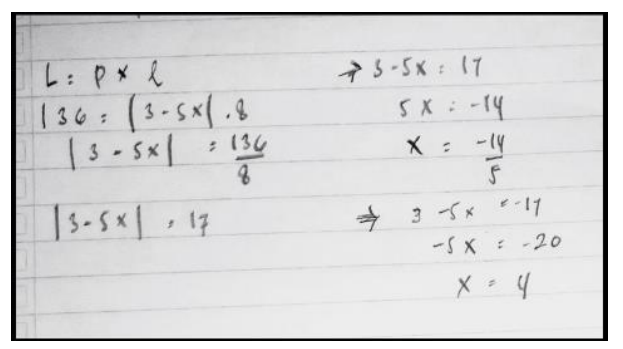

Gambar 9. Jawaban soal nomor 1 S-1

S-1 tidak mampu memahami masalah yang terdapat pada soal. S-1 tidak mampu menuliskan dan menjelaskan apa yang diketahui dan apa yang ditanyakan dari soal nomor 1 dengan tepat. Langkah kedua membuat rencana penyelesaian. S-1 mampu menjelaskan rencana untuk menyelesaikan soal dengan menggunakan rumus luas persegi panjang $L=p \times l$ untuk menentukan persamaan nilai mutlak linear satu variabel akan tetapi S-1 tidak tepat dalam menuliskan persamaan $|3 x-5|=17$. S-1 menuliskan $|3-5 x|=$ 17 pada lembar jawaban. Sehingga saat melaksanakan rencana penyelesaian S-1 tidak mampu menyelesaian permasalahan dengan tepat. Langkah terakhir yaitu memeriksa kembali. Langkah ini tidak dilakukan S-1.

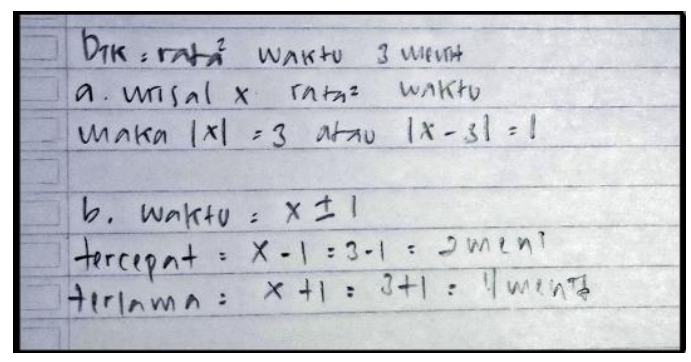

Gambar 10. Jawaban soal nomor 2 S-1

S-1 mampu memahami masalah yang terdapat pada soal. S-1 dapat menuliskan dan menjelaskan apa yang diketahui dari soal nomor 2 akan tetapi S-1 tidak menuliskan apa yang ditanyakan dari soal nomor 2 . Langkah kedua membuat rencana penyelesaian. S-1 mampu membuat dan menjelaskan rencana untuk menyelesaikan soal yaitu dengan menggunakan definisi nilai mutlak linear satu variabel. Dilanjutkan dengan melaksanakan rencana penyelesaian yaitu dengan menggunakan definisi nilai mutlak linear satu variabel. Akan tetapi S-1 tidak dapat menjelaskan pelaksanaan rencana penyelesaian dengan baik. Langkah terakhir yaitu memeriksa kembali. Langkah ini dilakukan oleh S-1.

Dari hasil penelitian, menunjukkan bahwa siswa dengan kategori kecemasan matematika tinggi dan sangat tinggi memiliki kesalahan yang serupa yaitu siswa sering kali tidak menuliskan informasi yang terdapat pada soal sehingga siswa mengalami kesulitan dalam membuat rencana penyelesaian dan menyelesaikan permasalahan serta siswa tidak memeriksa kembali langkah-langkah dan hasil jawabannya. Pemahaman siswa terhadap materi juga terbilang masih rendah. Siswa dengan kategori kecemasan matematika sedang sampai dengan sangat rendah mampu menyelesaikan permasalahan dengan baik, tetapi masih terdapat beberapa siswa yang pemahaman materinya kurang baik serta siswa tidak teliti dalam menyelesaikan permasalahan sehingga hasil penyelesaian yang didapat tidak tepat. Penelitian ini sejalan dengan hasil penelitian Sakarti (2018) yang menyatakan semakin tinggi kecemasan matematika siswa, maka kemampuan pemecahan masalahnya akan semakin rendah. Hal ini juga berlaku untuk keadaan sebaliknya. Semakin rendah kecemasan matematika siswa, maka kemampuan pemecahan masalahnya akan semakin tinggi

\section{KESIMPULAN}

Berdasarkan hasil penelitian yang sudah dilakukan, maka dapat ditarik kesimpulan bahwa siswa dengan kategori kecemasan rendah dan sangat rendah cenderung memiliki kemampuan pemecahan masalah yang sangat baik. Siswa mampu memenuhi keempat langkah pemecahan masalah yang dikemukakan Polya. Siswa dengan kategori kecemasan sedang cenderung memiliki kemampuan pemecahan masalah yang baik dan beberapa siswa memiliki kemampuan pemecahan masalah yang cukup. Siswa mampu memahami masalah dan 
membuat rencana penyelesaian, tetapi siswa tidak teliti saat melaksanakan rencana penyelesaian sehingga siswa mengalami kesulitan menemukan jawaban yang tepat. Siswa dengan kategori kecemasan tinggi dan sangat tinggi cenderung memiliki kemampuan pemecahan masalah yang kurang. Kesalahan yang sering terjadi karena siswa tidak menuliskan atau pun tidak teliti saat menuliskan informasi yang terdapat pada soal dan pemahaman siswa terhadap materi juga masih rendah sehingga siswa tidak mampu menyelesaikan soal dengan tepat.

\section{DAFTAR PUSTAKA}

Agsya, F. M., Maimunah, \& Roza, Y. (2019). Analisis Kemampuan Pemecahan Masalah ditinjau dari Motivasi Belajar Matematika Siswa MTs. Symmetry, 4(2), 31-44.

Anita, I. W. (2014). Pengaruh Kecemasan Matematika (Mathematics Anxiety) Terhadap Kemampuan Koneksi Matematis Siswa SMP. Infinity Journal, 3(1), 125-132.

Anita, N., Rahmawati, A., \& Asriningsih, T. M. (2019). Pemecahan Masalah Matematika Siswa Ditinjau Dari Tingkat Kecemasan Matematika. Prosiding Seminar Nasional Integrasi Matematika Dan Nilai Islami, 3(1), 206-211. http:// conferences.uin-malang.ac.id/index.php/SIMANIS/article/view/940

Aunurrofiq, M., \& Junaedi, I. (2017). Kecemasan Matematik Siswa dalam Menyelesaikan Soal-Soal Pemecahan Masalah. UMJER: Unnes Journal of Mathematics Education Research, 6(2), 157-166.

Hakim, R. N., \& Adirakasiwi, A. G. (2021). Analisis Tingkat Kecemasan Matematis Siswa SMA. JPMI: Jurnal Pembelajaran Matematika Inovatif, 4(4), 809-816. https://doi.org/10.22460/jpmi.v4i4.809-816

Hidayat, W., \& Ayudia, D. B. (2019). Kecemasan Matematik Dan Kemampuan Pemecahan Masalah Matematis Siswa SMA. Kalamatika: Jumal Pendidikan Matematika, 4(2), 205-214. https://doi.org/10.22236/kalamatika.vol4no2.2019pp205-214

Ikhsan, M. (2019). Pengaruh Kecemasan Matematis Terhadap Hasil Belajar Matematika. De Fermat : Jurnal Pendidikan Matematika, 2(1), 1-6. https://doi.org/10.36277/defermat.v2i1.28

Kemendikbud. (2021). SKB Empat Menteri Tentang Panduan Penyelenggaraan Pembelajaran Di Masa Pandemic Coronavirus Disease 2019 (Covid-19).

Lestari, H., Fitriza, R., \& A, H. (2020). Pengaruh Kecemasan Matematika (Mathematics Anxiety) Terhadap Kemampuan Pemecahan Masalah Peserta Didik Kelas VII MTs. Jurnal Matematika Dan Pendidikan Matematika, 4(1), 103-113.

Mawaddah, S., \& Anisah, H. (2015). Kemampuan Pemecahan Masalah Matematis Siswa pada Pembelajaran Matematika dengan Menggunakan Model Pembelajaran Generatif (Generative Learning) di SMP. EDUMAT Jurnal Pendidikan Matematika, 3(2), 166-175.

Mulyana, A., Senajaya, A. J., \& Ismunandar, D. (2021). Indikator-Indikator Kecemasan Belajar Matematika Daring Di Era Pandemik Covid- 19 Menurut Perspektif Siswa Sma Kelas X. Proximal: Jurnal Penelitian Matematika Dan Pendidikan Matematika, 4(1), 14-22. https://doi.org/10.30605/proximal.v4i1.501

Ningsih, E. F. (2016). Proses Berpikir Mahasiswa dalam Pemecahan Masalah Aplikasi Integral ditinjau dari Kecemasan Belajar Matematika (Math Anxiety). Iqra', 1(2), 191-216.

Rahmmatiya, R., \& Miatun, A. (2020). Analisis Kemampuan Pemecahan Masalah Matematis Ditinjau dari Resieliensi Matematis Siswa SMP. Teorema: Teori Dan Riset Matematika, 5(September), 187-202.

Rangkuti, N. M. E. (2017). Pengarub Kecemasan Matematika Terbadap Prokrastinasi Akademik Siswa SMA Negeri 2 Kuta Bali. UNIVERSITAS ISLAM NEGERI MAULANA MALIK IBRAHIM MALANG.

Rizki, F., Marethi, I., \& Rafianti, I. (2019). Pengaruh Kecemasan Matematika terhadap Kemampuan Pemecahan Masalah Siswa di SMA. GAUSS: Jumal Pendidikan Matematika, 2(2), 11. https://doi.org/10.30656/gauss.v2i2.1750

Sakarti, H. (2018). Hubungan Kecemasan dan Kemampuan Siswa dalam Menyelesaikan Masalah Matematika. Jurnal Pendidikan Informatika Dan Sains (JPIS), 7(1), 28-41.

https://journal.ikippgriptk.ac.id/index.php/saintek/article/view/766/685 
Satriyani. (2016). Pengaruh Kecemasan Matematika (Mathematics Anxiety) Dan Gender Terhadap Kemampuan

Pemecahan Permasalahan Matematika [Universitas Islam Negeri Syarif Hidayatullah].

https://www.google.com/url?sa=t\&source=web\&rct=j\&url=http:// repository.uinjkt.ac.id

Setyawati, A., \& Ratu, N. (2021). Analisis Kesulitan Belajar Matematika Siswa SMP pada Materi Aljabar

Ditinjau dari Mathematics Anxiety. Jurnal Cendekia : Jurnal Pendidikan Matematika, 5(3), 2941-2953.

https://doi.org/10.31004/cendekia.v5i3.957

Vendiagrys, L., Junaedi, I., \& Masrukan. (2015). Analisis Kemampuan Pemecahan Masalah Matematika Soal Setipe Timss Berdasarkan Gaya Kognitif Siswa pada Pembelajaran Model Problem Based Learning. UJMER, 4(1), 34-41.

Wati, I. (2021). Analisis Kemampuan Pemecahan Masalah Matematika Siswa Kelas X SMA Muhammadiyah Sungguminasa Berdasarkan Langkah Polya Ditinjau dari Gaya Berpikir Gregorc. 